\title{
Effects of Cerium Addition on Solidification Behaviour and Intermetallic Structure of Novel Al-Cu-Li Alloys
}

\author{
Yu Xinxiang1， Yin Dengfeng ${ }^{1,2}, \quad$ Yu Zhiming ${ }^{1}, \quad$ Zhang Yiran', $\quad$ Li Shufei $^{1}$ \\ ${ }^{1}$ Central South University, Changsha 410083, China; ${ }^{2}$ Yantai Nanshan University, Yantai 265713, China
}

\begin{abstract}
The microstructure evolutions of novel $\mathrm{Al}-\mathrm{Cu}-\mathrm{Li}$ alloys with rare earth cerium $(\mathrm{Ce})$ additions $(0,0.1,0.3$, and 0.5 , wt $\%)$ were investigated. The as-cast samples were characterized by optical microscopy, scanning electron microscopy, X-ray diffraction meter and electron probe microanalysis with wavelength dispersive spectroscopic. The microstructural observation shows that the grains are significantly refined with increasing the addition of $\mathrm{Ce} . \mathrm{Mg}+\mathrm{Ag}$-rich $\mathrm{Al}_{7} \mathrm{Cu}_{4} \mathrm{Li}$ intermetallic phase can be observed in all experimental alloys except for the one with addition of $0.5 \mathrm{wt} \% \mathrm{Ce}$, which an extra gray $\mathrm{CuSi}(\mathrm{AgMg})$ phase emerges. Furthermore, the coarse rodlike $\mathrm{Al}_{2} \mathrm{CuLi}$ phase is completely absent upon Ce level up to $0.3 \mathrm{wt} \%$. The analysis shows that the Ce addition introduces changes in the precipitation sequence and consequently in the solidification behavior of the alloy. It is deduced that the grain refinement is mainly the result of the primary $\mathrm{Al}_{8} \mathrm{Cu}_{4} \mathrm{Ce}$ promoting $\alpha(\mathrm{Al})$ nucleation and further prohibiting the grain growth for the experimental alloys with cerium addition.
\end{abstract}

Key words: Al-Cu-Li alloy; cerium element; grain refinement; intermetallic phase

As the reduction of density is one of the essential requirements for innovative materials to be used in aerospace applications, great efforts have been devoted to the study of Al-Li based alloys ${ }^{[1,2]}$. A novel Al-Cu-Li based alloys can reach an extremely high strength through a fine scale precipitate distribution mostly composed of high-aspect ratio plate-like $T_{1}\left(\mathrm{Al}_{2} \mathrm{CuLi}\right)$ precipitates ${ }^{[3-6]}$. Therefore the replacement of 7xxx alloys in aircraft metallic structures by Al-Cu-Li alloys, which have similar mechanical properties, could induce a $6 \%$ reduction in mass $^{[7]}$. The types of precipitates observed in such a complex Al-Cu-Li alloy system primarily include: $\mathrm{Al}_{2} \mathrm{Cu}$ $(\theta), \quad \mathrm{AlLi}(\delta), \mathrm{Al}_{3} \mathrm{Zr}, T_{1}\left(\mathrm{Al}_{2} \mathrm{CuLi}\right), T_{2}\left(\mathrm{Al}_{6} \mathrm{CuLi}_{3}\right), T_{\mathrm{B}}$ $\left(\mathrm{Al}_{7} \mathrm{Cu}_{4} \mathrm{Li}\right), R\left(\mathrm{Al}_{5} \mathrm{CuLi}_{3}\right)$, and $S\left(\mathrm{Al}_{2} \mathrm{CuMg}\right)^{[8]}$.

Rare earth elements in conventional casting aluminum alloys have shown beneficial effects on melting and solidification. These elements reduce the contents of gases and some impurities, and the spacing between secondary

dendrite $\operatorname{arms}^{[9]}$. It was reported that the Ce content affected the grain size and the mechanical properties of $\mathrm{Al}-\mathrm{Cu}$ alloys ${ }^{[10]}$. Chaubey et al. ${ }^{[11]}$ studied the effect of $\mathrm{Ce}$ alloying in $7055 \mathrm{Al}$ alloy and reported that a dendritic structure could be refined, the morphology of precipitates changed from the spherical shape to the needle when $\mathrm{Ce}$ content varied from $0.1 \%$ to $0.4 \%$ (mass fraction). Lai et al. ${ }^{[12]}$ also found that the addition of Ce could remarkably refine the as cast grains and the eutectic microstructure.

To date, the influences of Ce additions from $0.1 \%$ to $0.5 \%$ on the microstructures and the intermetalic characterization of $\mathrm{Al}-5.8 \% \mathrm{Cu}-1.3 \% \mathrm{Li}$ based alloys with the elevated $\mathrm{Cu} / \mathrm{Li}$ ratios have not been reported in literatures. The aim of the present work is to investigate the influences of various $\mathrm{Ce}$ additions on the cast microstructure and the solidification behaviour of novel Al-Cu-Li alloys.

\section{Experiment}

\footnotetext{
Received date: June 02,2015
}

Foundation item: Research Foundation of the General Armament Department (6140506); Foundation for Sci \& Tech Development Project of Shandong (2014GGX102006)

Corresponding author: Yin Dengfeng, Ph. D., Associate Professor, School of Materials Science and Engineering, Central South University, Changsha 410083, P. R. China, Tel: 0086-731-88879341, E-mail: dfyin@126.com 
The nominal compositions of the investigated alloys are listed in Table 1. Master alloys of Al-Zr, Al-Ce and Al-Cu and pure elements of $\mathrm{Ag}, \mathrm{Mg}, \mathrm{Li}$ and $\mathrm{Al}$ were melted in a vacuum induction melting furnace under a controlled atmosphere of argon gas. Lithium addition was made by plunging Li wrapped in aluminium foil ${ }^{[13]}$.

Specimens cut from the ingot were subjected to optical and electronic microscopy observations. Grain structures of the specimens were determined after being anodized with Barker's reagent and viewed with cross-polarized light on Leica DMILM optical microscope (OM). Phase analysis was performed with $\mathrm{X}$ ray diffractometer (XRD, Rigaku D/max 2500). A Quanta-200 environmental scanning electron microscope (SEM) was used for the evaluation of the microstructural features of the alloy. The wavelength-dispersive X-ray spectrometer (WDS) microanalysis of the intermediate phases in arbitrarily selected area was performed on JEOL JXA-8230 electron microprobe analysis (EPMA) instrument.

\section{Results}

\subsection{Microstructure observation}

Optical micrographs of the grain structures of the alloys with various contents of $\mathrm{Ce}$ are presented in Fig.1. As compared with the alloy without $\mathrm{Ce}$, it is clear that addition of $0.1 \% \mathrm{Ce}$ results in grain refinement. With addition of $0.3 \% \mathrm{Ce}$, the grain size is reduced significantly. The grain size of the alloy with $0.3 \% \mathrm{Ce}$ in Fig.1c is only a third of that in Fig.1a. Further increase of Ce only leads to a slight decrease in grain size. As shown in Fig.1d, the grain size of the alloy with $0.5 \% \mathrm{Ce}$ is close to that with $0.3 \% \mathrm{Ce}$. However, a refinement of the dendritic substructure is not seen within the grains as shown in Fig.1c and Fig.1d.

Fig. 2 shows the SEM images of as-cast experimental alloys with various contents of Ce. Coarse particles of secondary phases are distributed both within the interiors of dendrite cells and on the dendrite boundaries. Three types of phases could be distinctly distinguished because of well-defined differences in their morphologies and brightnesses. Furthermore, Fig. 3 shows high magnification morphologies of intermetallic structures at area in panel as show in Fig.2. Fig.2a (Fig.3a) show the micrograph of Alloy A. It is clearly seen from Fig.2a (Fig.3a) that the primary eutectic particles are present in the form of coarse rodlike shape and continuous phase. Fig.2b (Fig.3b) presents the microstructure of Alloy B. It is obvious that the number of coarse needle-shaped phase is abruptly reduced. It is clearly observed that the size and interflake spacing of intermetallic particles significantly decrease with the addition of Ce. Fig.1c and 1d (Fig.2c and 2d) show the microstructures of Alloy $\mathrm{C}$ and Alloy $\mathrm{D}$, respectively. It is observed that a new morphology "skeletal" (some times called "Chinese script") particles are formed and their volume fractions rise with the increasing addition of $\mathrm{Ce}$.

Table 1 Nominal compositions of the alloys (wt \%)

\begin{tabular}{ccccccc}
\hline Alloy code & $\mathrm{Ce}$ & $\mathrm{Li}$ & $\mathrm{Cu}$ & $\mathrm{Mg}$ & $\mathrm{Ag}$ & $\mathrm{Zr}$ \\
\hline Alloy A & - & 1.3 & 5.8 & 0.4 & 0.4 & 0.14 \\
Alloy B & 0.1 & 1.3 & 5.8 & 0.4 & 0.4 & 0.14 \\
Alloy C & 0.3 & 1.3 & 5.8 & 0.4 & 0.4 & 0.14 \\
Alloy D & 0.5 & 1.3 & 5.8 & 0.4 & 0.4 & 0.14 \\
\hline
\end{tabular}
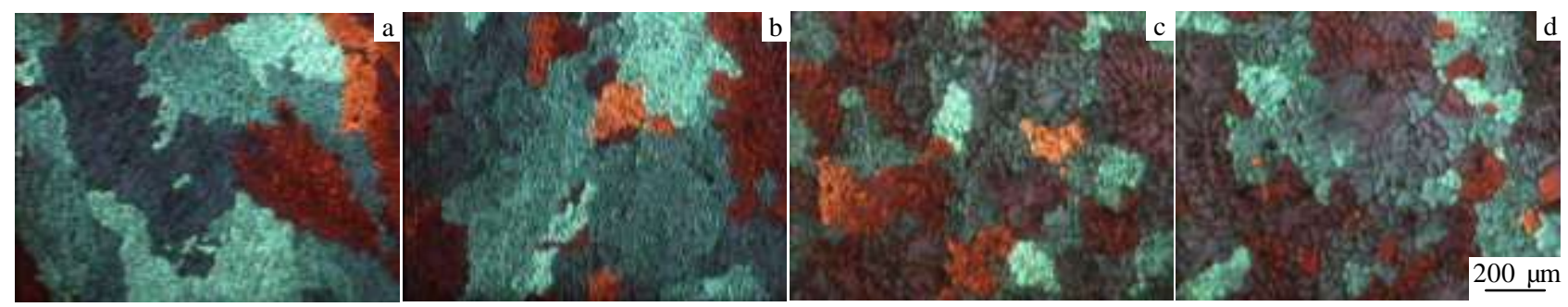

Fig.1 Optical micrographs of as-cast experimental alloys with different Ce contents: (a) $0 \% \mathrm{Ce}$, (b) $0.1 \% \mathrm{Ce}$, (c) $0.3 \% \mathrm{Ce}$, and (d) $0.5 \% \mathrm{Ce}$
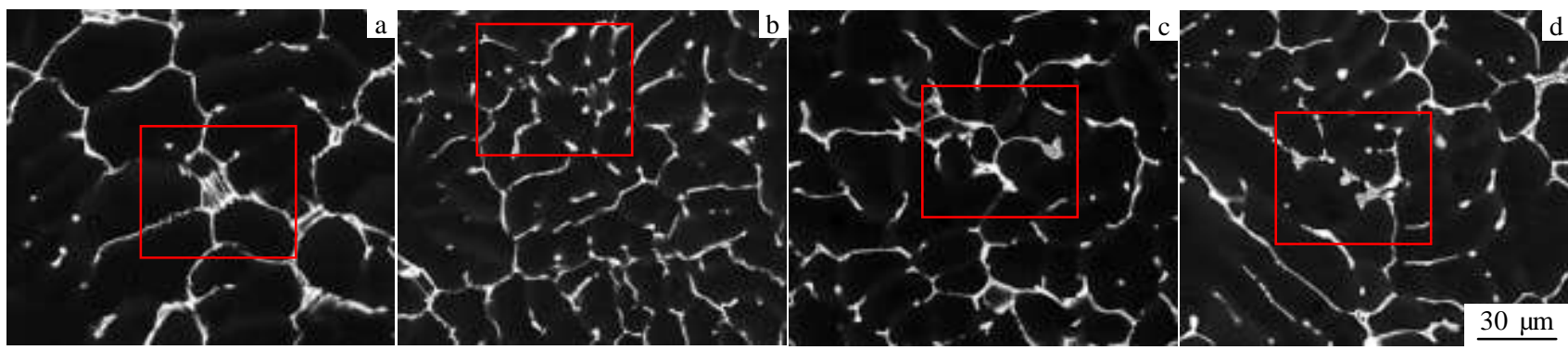

Fig.2 SEM images of as-cast experimental alloys with different Ce contents: (a) $0 \% \mathrm{Ce}$, (b) $0.1 \% \mathrm{Ce}$, (c) $0.3 \% \mathrm{Ce}$, and (d) $0.5 \% \mathrm{Ce}$ 

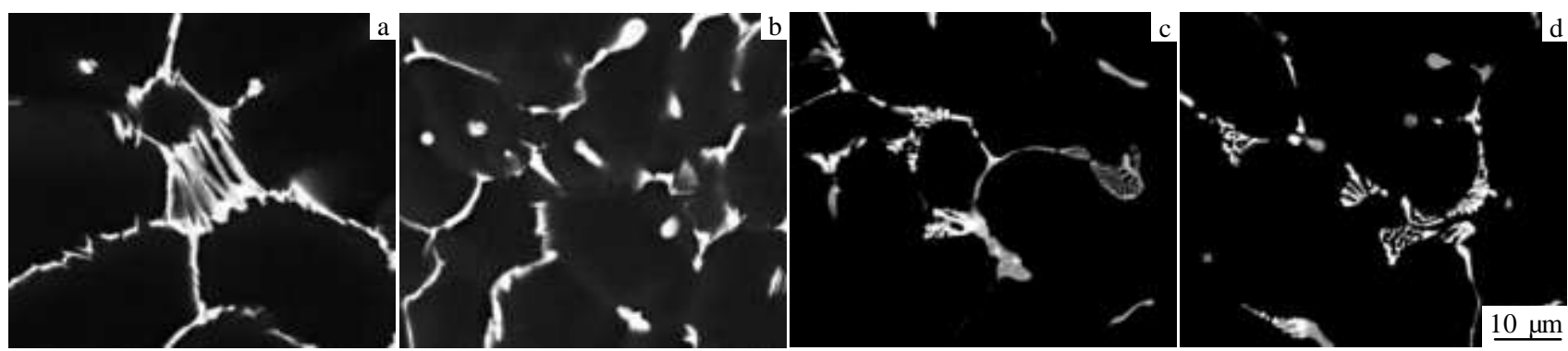

Fig.3 High magnification morphologies of intermetallic structures at areas in panel as shown in Fig.2: (a) $0 \% \mathrm{Ce}$, (b) $0.1 \% \mathrm{Ce}$, (c) $0.3 \% \mathrm{Ce}$, and (d) $0.5 \% \mathrm{Ce}$

Moreover, the coarse rodlike phase is completely absent.

\subsection{Segregation of the alloying elements}

Fig.4 shows the high magnification SEM microstructures and the elements mappings of the studied Alloy A and Alloy $\mathrm{D}$ carried out by EPMA where $\mathrm{Li}$ is hard to be detected for its light mass. In both alloys, $\mathrm{Cu}, \mathrm{Ag}, \mathrm{Mg}$ and $\mathrm{Ce}$ are all non-uniformly distributed. While $\mathrm{Zr}$ is uniformly distributed within the $\mathrm{Al}$ matrix. $\mathrm{Cu}$ atoms are enriched in the coarse continuous phases. For the Alloy A, the Mg and $\mathrm{Ag}$ tend to be concentrated together at the ends of these red continuous phases. Yet upon the addition of $0.5 \% \mathrm{Ce}$, it does not seem to be a segregation together of $\mathrm{Mg}$ and $\mathrm{Ag}$ at the ends of $\mathrm{Cu}$ rich phase at the place where the segregation of Ce occurs. The $\mathrm{Zr}$ segregation becomes light colored after the addition of $\mathrm{Ce}$, showing wathet blue, which means the $\mathrm{Zr}$ content in the matrix gives a rise. Thus as compared with alloy without $\mathrm{Ce}$, it is clear that addition of $0.5 \% \mathrm{Ce}$ results in a high-density dispersion of $\mathrm{Zr}$ atoms segregating more strongly during solidification.

\subsection{Phase constitution}

EPMA was used to verify the constitution of phases formed during solidification in the studied alloy. As shown in Fig.5a (Alloy A), the coarse continuous particle can be divided into two parts, A and B. Part A gives a lamellar structure presenting a typical eutectic structure, while part $\mathrm{B}$ appears to be flat and smooth. Figs.5b and $5 \mathrm{c}$ show the microstructures of Alloy B and Alloy C. It is found that part $\mathrm{C}$ is lighter than part $\mathrm{D}$. In addition, the coarse continuous particle can be divided into three parts (E, F, G) for Alloy D (Fig.5a) based on its morphology and brightness.

The WDS analysis of point 1 in the part A, point 2 in the part B, and point 3 in the matrix for Fig.5a are listed in Table 2. The analysis results reveal the presence of three main phases in Alloy A: $\alpha(\mathrm{Al})$, eutectic structure of $\alpha(\mathrm{Al})$ and $\mathrm{Zr}$ bearing $\mathrm{AlCu}$ phase (part A), AlCu phase (part B). Table 3 and Table 4 show the WDS analysis of point 1 in the part $\mathrm{C}$, point 2 in the part $\mathrm{D}$, and point 3 in the matrix for Fig.5b and Fig.5c, respectively. The contents of Ag and $\mathrm{Mg}$ in part $\mathrm{D}$ are all about twofold and threefold of that in

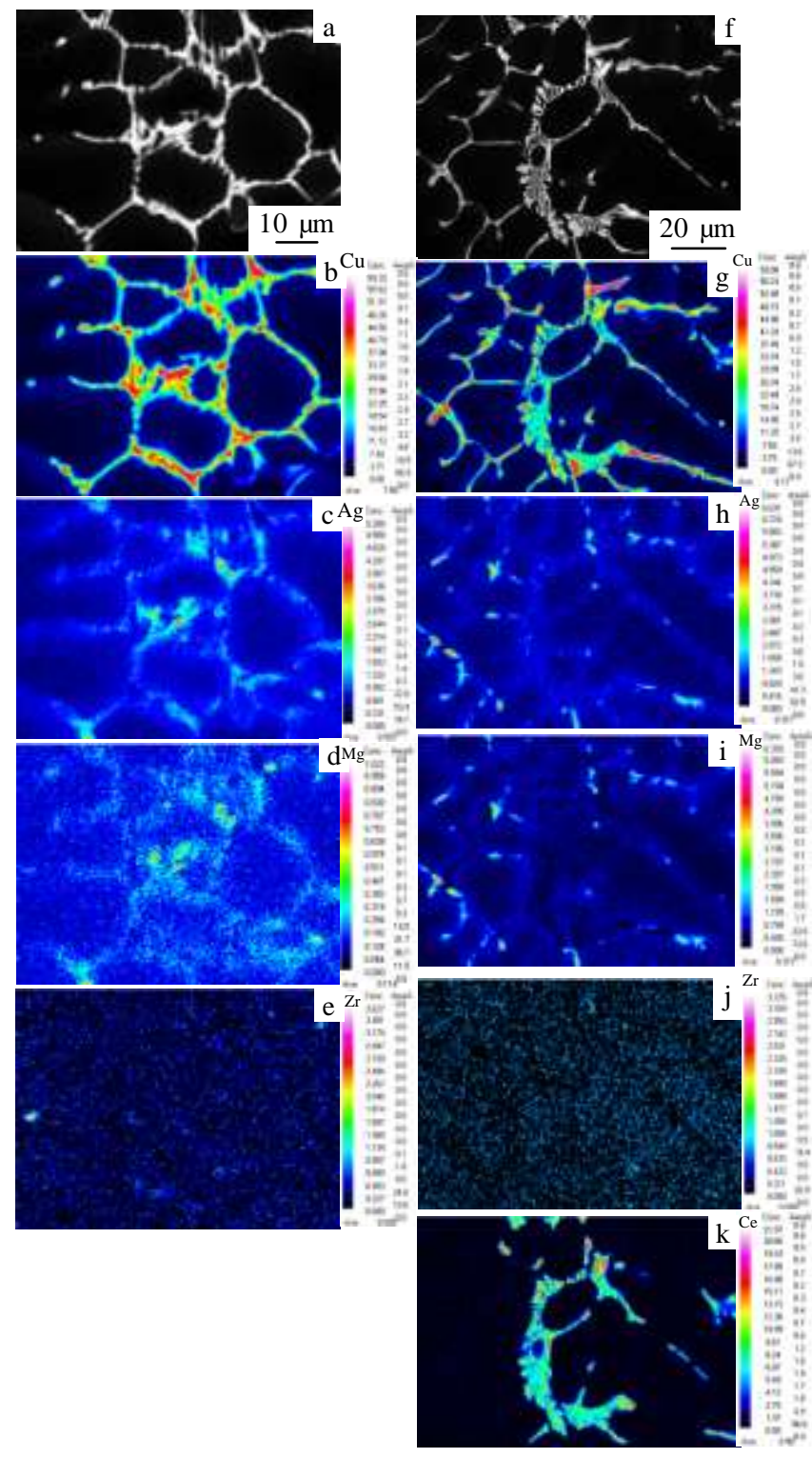

Fig.4 Elements map-scanning of the as-cast structures: (a,f) SEM images, (b, g) Cu, (c, h) Ag, (d, i) Mg, (e, j) $\mathrm{Zr}$ and (k) $\mathrm{Ce} ;(\mathrm{a} \sim \mathrm{e}) 0 \% \mathrm{Ce}$, (f $\sim \mathrm{k}) 0.5 \% \mathrm{Ce}$ 

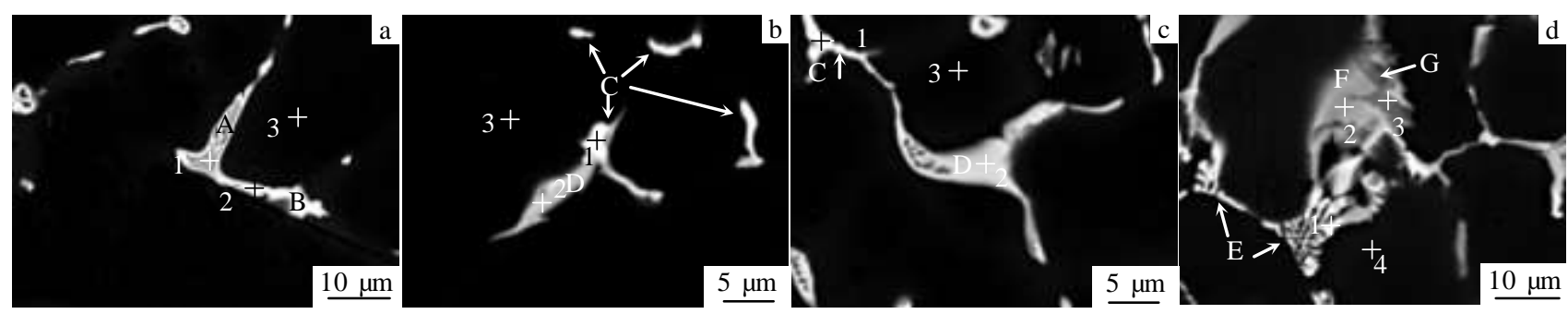

Fig.5 SEM images of the phase constitution in the as-cast structures: (a) $0 \% \mathrm{Ce}$, (b) $0.1 \% \mathrm{Ce},(\mathrm{c}) 0.3 \% \mathrm{Ce}$, and (d) $0.5 \% \mathrm{Ce}$

Table 2 WDS analysis of the Alloy A without addition Ce (at\%)

\begin{tabular}{cccccccccc}
\hline Point & $\mathrm{Al}$ & $\mathrm{Cu}$ & $\mathrm{Ag}$ & $\mathrm{Mg}$ & $\mathrm{Zr}$ & $\mathrm{Fe}$ & $\mathrm{Si}$ & $\mathrm{T}$ \\
\hline 1 & 79.7479 & 19.2308 & 0.0814 & 0.1579 & 0.0797 & 0.6020 & 0.0803 & 100.0000 \\
2 & 70.1963 & 28.5786 & 0.1122 & 0.2751 & - & 0.6783 & 0.1594 & 99.9999 \\
3 & 98.1477 & 1.6552 & 0.0600 & 0.0680 & 0.0039 & 0.0076 & 0.0577 & 100.0000 \\
\hline
\end{tabular}

Table 3 WDS analysis of the Alloy B with addition of $0.1 \% \mathrm{Ce}($ at $\%)$

\begin{tabular}{ccccccccccc}
\hline Point & $\mathrm{Al}$ & $\mathrm{Cu}$ & $\mathrm{Ag}$ & $\mathrm{Mg}$ & $\mathrm{Zr}$ & $\mathrm{Fe}$ & $\mathrm{Si}$ & $\mathrm{Ce}$ & Total \\
\hline 1 & 70.7619 & 27.2500 & 0.0796 & 0.1448 & 0.3132 & 0.2846 & 0.0147 & 1.1512 & 100.0000 \\
2 & 75.1333 & 25.0180 & 0.1323 & 0.3981 & - & 0.0452 & 0.0588 & 0.0104 & 99.9999 \\
3 & 98.7701 & 1.0678 & 0.0651 & 0.0720 & 0.0340 & 0.0148 & 0.0119 & 0.0043 & 100.0000 \\
\hline
\end{tabular}

Table 4 WDS analysis of the Alloy $\mathrm{C}$ with addition of $0.3 \% \mathrm{Ce}($ at \%)

\begin{tabular}{cccccccccc}
\hline Point & $\mathrm{Al}$ & $\mathrm{Cu}$ & $\mathrm{Ag}$ & $\mathrm{Mg}$ & $\mathrm{Zr}$ & $\mathrm{Fe}$ & $\mathrm{Si}$ & $\mathrm{Ce}$ & Total \\
\hline 1 & 74.2398 & 22.9415 & 0.0627 & 0.2148 & 0.1668 & 0.1923 & 0.0529 & 2.1281 & 100.0000 \\
2 & 76.4389 & 22.1606 & 0.1254 & 0.5621 & - & 0.7030 & 0.0496 & 0.0100 & 100.0000 \\
3 & 98.3532 & 1.4555 & 0.0621 & 0.0799 & 0.0226 & 0.0059 & 0.0119 & 0.0207 & 100.0000 \\
\hline
\end{tabular}

Table 5 WDS analysis of the Alloy D with addition of $0.5 \% \mathrm{Ce}($ at $\%)$

\begin{tabular}{cccccccccc}
\hline Point & $\mathrm{Al}$ & $\mathrm{Cu}$ & $\mathrm{Ag}$ & $\mathrm{Mg}$ & $\mathrm{Zr}$ & $\mathrm{Fe}$ & $\mathrm{Si}$ & $\mathrm{Ce}$ & $\mathrm{Total}$ \\
\hline 1 & 72.3726 & 24.0585 & 0.0673 & 0.0767 & 0.0458 & 0.3482 & 0.0554 & 2.9755 & 100.0000 \\
2 & 71.4645 & 27.8514 & 0.0476 & 0.0369 & 0.0587 & 0.4709 & 0.0589 & 0.0111 & 100.0000 \\
3 & 72.7691 & 23.4875 & 0.1777 & 1.9182 & 0.0183 & 0.0519 & 1.5615 & 0.0158 & 100.0000 \\
4 & 98.3530 & 1.4339 & 0.0658 & 0.0827 & 0.0216 & 0.0037 & 0.0118 & 0.0275 & 100.0000 \\
\hline
\end{tabular}

part $C$, respectively. The Ce tends to segregate within the $\mathrm{Cu}-\mathrm{Zr}$ rich phase. In addition, the WDS analysis of point 1 in part $\mathrm{E}$, point 2 in part $\mathrm{F}$, point 3 in part $\mathrm{G}$ and point 4 in the matrix for Fig.5d are listed in Table 5. As compared with $\mathrm{Ce}$ rich phase in Figs.5b and 5c, it is found that the $\mathrm{Zr}$ content in $\mathrm{Ce}$ rich phase is relatively low and the distribution of $\mathrm{Zr}$ is more uniform within the entire picture. A new dark phase (part G) enrichment with $\mathrm{Ag}, \mathrm{Mg}$ and $\mathrm{Si}$ is observed. Yet the $\mathrm{Ag}$ and $\mathrm{Mg}$ levels are measured to be very low both in point 1 (part E) and point 2 (part F). All the analyses show that the above results are in accordance with composition profiles along the line across the coarse phase which are indicated in Fig.6.

Fig.7 shows the XRD patterns of as-cast experimental alloys. It is clearly observed that there are mainly three intermetallic phases: $\mathrm{Al}_{2} \mathrm{CuLi}, \mathrm{Al}_{7} \mathrm{Cu}_{4} \mathrm{Li}, \mathrm{Al}_{8} \mathrm{Cu}_{4} \mathrm{Ce}$. However, non-observation of $\mathrm{Zr}$ or potential intermetallic phase may be attributed to small volume fraction $(<1 \%)$ of intermetallic compounds ${ }^{[14]}$. Based on both of qualitative and quantified analyses above, a summary about the characterizes of these intermetallic phases within each experimental alloy is presented in Table 6 . 

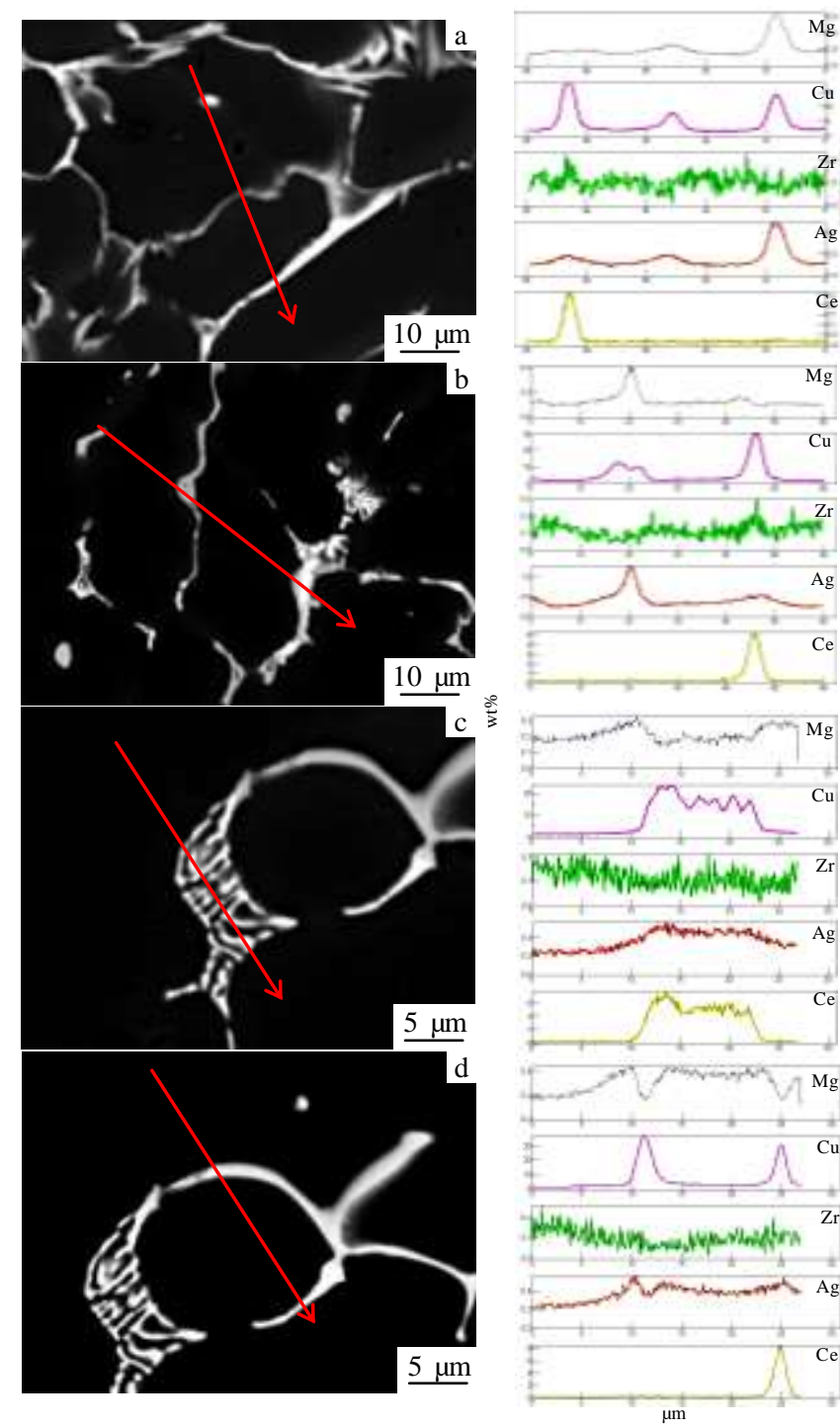

Fig.6 Composition profiles along the line across the coarse phase: (a) $0.1 \% \mathrm{Ce}$, (b) $0.3 \% \mathrm{Ce}$, and (c, d) $0.5 \% \mathrm{Ce}$

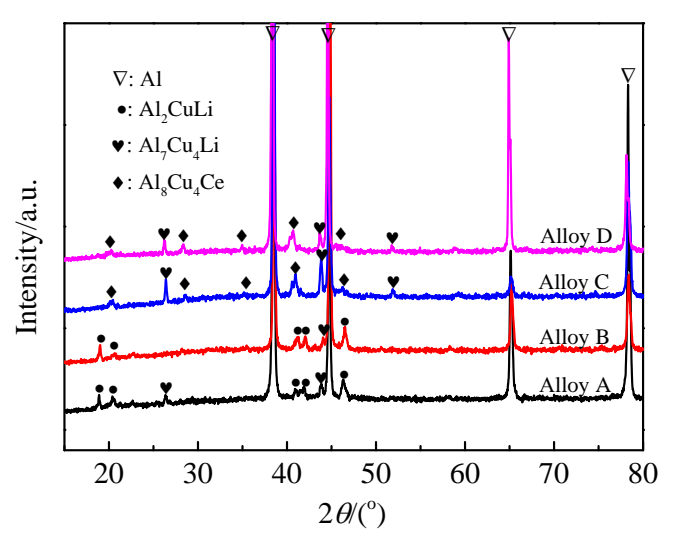

Fig.7 XRD patterns of as-cast experimental alloys with additions of $0 \%, 0.1 \%, 0.3 \%$ and $0.5 \% \mathrm{Ce}$
Table 6 Characterization of intermetallic phases within each experimental alloy

\begin{tabular}{|c|c|c|}
\hline Alloy code & Phase & Characterization \\
\hline Alloy A & $\begin{array}{c}\mathrm{Al}_{2} \mathrm{CuLi} \\
\mathrm{Al}_{7} \mathrm{Cu}_{4} \mathrm{Li}(\mathrm{AgMg})\end{array}$ & $\begin{array}{c}\text { Rod like, bright } \\
\text { Continuous phase, bright }\end{array}$ \\
\hline Alloy B & $\begin{array}{c}\mathrm{Al}_{2} \mathrm{CuLi} \\
\mathrm{Al}_{7} \mathrm{Cu}_{4} \mathrm{Li}(\mathrm{AgMg}) \\
\mathrm{Al}_{8} \mathrm{Cu}_{4} \mathrm{Ce}\end{array}$ & $\begin{array}{c}\text { Rod like, bright } \\
\text { Continuous phase, bright } \\
\text { Continuous phase, brighter }\end{array}$ \\
\hline Alloy C & $\begin{array}{c}\mathrm{Al}_{8} \mathrm{Cu}_{4} \mathrm{Ce} \\
\mathrm{Al}_{7} \mathrm{Cu}_{4} \mathrm{Li}(\mathrm{Ag} \mathrm{Mg})\end{array}$ & $\begin{array}{c}\text { "Skeletal", brighter } \\
\text { Continuous phase, bright }\end{array}$ \\
\hline Alloy D & $\begin{array}{c}\mathrm{Al}_{8} \mathrm{Cu}_{4} \mathrm{Ce} \\
\mathrm{Al}_{7} \mathrm{Cu}_{4} \mathrm{Li} \\
\mathrm{CuSi}(\mathrm{AgMg})\end{array}$ & $\begin{array}{c}\text { "Skeletal", brighter } \\
\text { Continuous phase, bright } \\
\text { Continuous phase, gray }\end{array}$ \\
\hline
\end{tabular}

\section{Discussion}

The grain sizes of an ingot can be altered by varying the composition of the alloy under given cooling conditions. As for the Al-Sc alloy, some researchers reported that grain sizes behave almost as a step function with increasing Sc content ${ }^{[15]}$. For the Sc content was increased beyond eutectic composition of $0.55 \%$, a dramatic reduction in the grain size was observed. That might be attributed to the refinement in grain size to the formation of intermetallic particles of the $\mathrm{L}_{2} \mathrm{Al}_{3} \mathrm{Sc}$ phase in the melt, which, they proposed, acted as nucleation sites for the remaining $\alpha(\mathrm{Al})$ to solidify ${ }^{[16]}$. Reference to the Al-Ce binary phase diagram ${ }^{[17]}$ shows that a eutectic reaction occurring at $650{ }^{\circ} \mathrm{C}$ will lead to a composition of $0.05 \%$ $\mathrm{Ce}$, resulting in the formation of $\alpha(\mathrm{Al})$ and the $\mathrm{Al}_{4} \mathrm{Ce}$ intermetallic phase. Analogously, the Ce content must be higher than $0.05 \%$ for the formation of the $\mathrm{Al}_{4} \mathrm{Ce}$ as the first phase and the nucleating agents. However, even addition of $0.1 \% \mathrm{Ce}$ does not lead to obvious grain refinement in the present experiment. This indicates that grain refinement is not the result of the nucleation initiation of the first $\mathrm{Al}_{4} \mathrm{Ce}$ which is attributed to high $\mathrm{Cu}$ addition in the present experiment.

Once the $\mathrm{Cu}$ level is up to $5.8 \%$, an isothermal section of $\mathrm{Al}-\mathrm{Cu}-\mathrm{Ce}$ ternary system phase diagram ${ }^{[18]}$ must be taken into consideration. As shown in Fig.8, three experimental alloys (Alloy B, Alloy C and Alloy D) are fallen into two different equilibrium fields (in the area of the dashed rectangular) at $590{ }^{\circ} \mathrm{C}$ and $540{ }^{\circ} \mathrm{C}$. The solidification sequences are illustrated as follows:

$$
\begin{aligned}
& \text { Alloy B: } L \rightarrow L+\partial(\mathrm{Al}) \rightarrow \partial(\mathrm{Al})+\tau_{1}\left(\mathrm{Al}_{8} \mathrm{Cu} \mathrm{Ce}_{4}\right)+\theta\left(\mathrm{Al}_{2} \mathrm{Cu}\right) \\
& \text { Alloy C }: L \rightarrow L+\partial(\mathrm{Al})+\tau_{1}\left(\mathrm{Al}_{8} \mathrm{Cu}_{4} \mathrm{Ce}\right) \rightarrow \partial(\mathrm{Al})+ \\
& \tau_{1}\left(\mathrm{Al}_{8} \mathrm{Cu}_{4} \mathrm{Ce}\right)+\theta\left(\mathrm{Al}_{2} \mathrm{Cu}\right) \\
& \quad \text { alloy } \mathrm{D}: L \rightarrow L+\partial(\mathrm{Al})+\tau_{1}\left(\mathrm{Al}_{8} \mathrm{Cu}_{4} \mathrm{Ce}\right) \rightarrow \partial(\mathrm{Al})+\tau_{1}\left(\mathrm{Al}_{8} \mathrm{Cu}_{4} \mathrm{Ce}\right)
\end{aligned}
$$

At least at $590{ }^{\circ} \mathrm{C}$, it is obviously seen that both Alloy $\mathrm{C}$ and Alloy $\mathrm{D}$ own a primary $\mathrm{Al}_{8} \mathrm{Cu}_{4} \mathrm{Ce}$ phase which acts as 

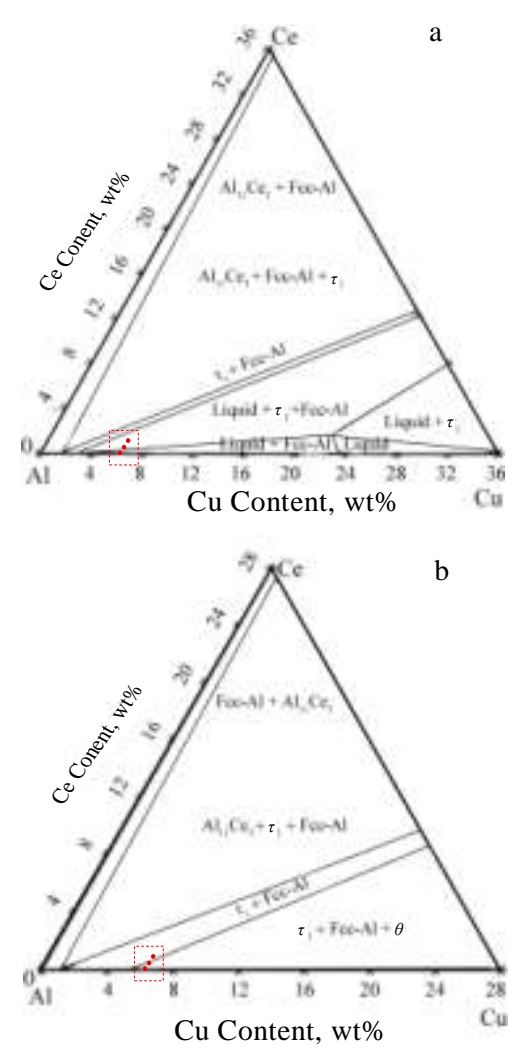

Fig. 8 Isothermal sections of $\mathrm{Al}-\mathrm{Cu}-\mathrm{Ce}$ phase diagram at $590{ }^{\circ} \mathrm{C}$ (a) and $540{ }^{\circ} \mathrm{C}(\mathrm{b})^{[18]}$

nucleating agents for remainder liquid solidified to $\alpha(\mathrm{Al})$ continually. Thus, with the addition level of Ce element above $0.3 \%$, grain nucleation number are significantly raised which is attributed to increased heterogeneous nucleation on primary $\mathrm{Al}_{8} \mathrm{Cu}_{4} \mathrm{Ce}$ phase.

In addition, $\mathrm{Si}$ and co-workers ${ }^{[19]}$ found that the addition of $0.3 \% \mathrm{Ce}$ gives the highest thermal resistance. They attributed their results to $\mathrm{Ce}$ atoms being segregated at the solidification front of the dendrites so as to increase the region of compositional supercooling and reduce the arm spacing of secondary dendrites. However, addition of $0.3 \%$ $\mathrm{Ce}$ and $0.5 \% \mathrm{Ce}$ do not the dendritic substructure within the grains in the present experiment (Fig.1c and 1d). That may be attributed to Alloy $\mathrm{C}$ and Alloy D with the Ce concentration which exceeds the eutectic point to a great extent. Once supersaturated $\mathrm{Ce}$ atoms are expelled from the solidified grains and accumulated at the front of the interface between solid and liquid during solidification, a large number of primary $\mathrm{Al}_{8} \mathrm{Cu}_{4} \mathrm{Ce}$ will be formed quickly by the decomposing eutectic reaction. While the primary $\mathrm{Al}_{8} \mathrm{Cu}_{4} \mathrm{Ce}$ will prevent further growth of the grains. So it can be deduced that the grain refinement is mainly the result of the primary $\mathrm{Al}_{8} \mathrm{Cu}_{4} \mathrm{Ce}$ promoting nucleation and prohibiting the grain growth for the Alloy $\mathrm{C}$ and Alloy D.

When the compositions of Al-Cu-Li alloys developed in the present work were plotted on a modified version of
Silcock's phase diagram, they fell into three different equilibrium fields ${ }^{[20]}$. Alloy with $1.3 \% \mathrm{Li}$ falls on the boundary of an equilibrium three-phase field with $\alpha(\mathrm{Al})$, $T_{\mathrm{B}}\left(\mathrm{Al}_{7} \mathrm{Cu}_{4} \mathrm{Li}\right), \mathrm{Al}_{2} \mathrm{CuLi}$. These interpretations are also in good agreement with the XRD /WDS findings at the present work.

\section{Conclusions}

1) The grain sizes are significantly refined with increasing of the addition content of rare earth $\mathrm{Ce}$.

2) The grain refinement is mainly the result of the primary $\mathrm{Al}_{8} \mathrm{Cu}_{4} \mathrm{Ce}$ promoting nucleation and prohibiting the grain growth for the experimental alloys.

3) The $\mathrm{Ce}$ addition introduces changes in the precipitation sequence and consequently in the solidification behavior of the present alloys.

\section{References}

1 Gaber A, Afify N. Physica B: Condensed Matter[J], 2002, 315(1-3): 1

2 Meric C. Materials Research Bulletin[J], 2000, 35: 1479

3 Yu X X, Yu Z M, Ying D F et al. Rare Metal Materials and Engineering[J], 2014, 43(2): 495 (in Chinese)

4 Yoshimura R, Konno T J, Abe E et al. Acta Materialia[J], 2003, 51: 4251

5 Gault B, Geuser F, Bourgeois L et al. Ultramicroscopy[J], 2011, 111: 207

6 Murayama M, Hono K. Scripta Materialia[J], 2001, 44: 701

7 Proton V, Alexis J, Andrieu E et al. Corrosion Science $[\mathrm{J}]$, 2014, 80: 494

8 Kumar K S, Brown S A, Pickens J R. Acta Material[J], 1996, 44(5): 1899

9 Xiao D H, Huang B Y. Transactions of Nonferrous Metals Society of China[J], 2007, 17: 1181

10 Chen K H, Fang H C, Zhang Z et al. Materials Science Forum [J], 2007, 546: 1021

11 Chaubey A K, Mohapatra S, Jayasankar K et al. Transactions of The Indian Institute of Metals[J], 2009, 62(6): 539

12 Lai J P, Jiang R P, Liu H S et al. Journal of Central South University [J], 2012, 19: 869

$13 \mathrm{Yu}$ X X, Yin D F, Yu Z M et al. Rare Metal Materials and Engineering[J], 2014, 43(5): 1061 (in Chinese)

14 Li Q L, Xia T D, Lan Y F et al. Journal of Alloys and Compounds[J], 2013, 562: 25

15 Norman A F, Prangnell P B, Mcewen R S. Acta Materialia[J], 1998, 46(16): 5715

16 Wen S P, Xing Z B, Huang $\mathrm{H}$ et al. Materials Science and Engineering $A[\mathrm{~J}], 2009,516(1-2): 42$

17 Vadim S Z, Nikolai A B, Michael V G. Casting Aluminum Alloys[M]. UK: Elsevier Science, 2007: 8

18 Bo H, Jin S, Zhang L G et al. Journal of Alloys and Compounds[J], 2009, 484: 286

19 Si N C, Guo Y, Li G Q et al. Transactions of Nonferrous 


\title{
$\mathrm{Ce}$ 含量对新型 $\mathrm{Al}-\mathrm{Cu}-\mathrm{Li}$ 合金的凝固行为及其相的影响
}

\author{
余金祥 ${ }^{1}$, 尹登峰 ${ }^{1,2}$, 余志明 ${ }^{1}$, 张亦然 ${ }^{1}$, 李树飞 ${ }^{1}$ \\ (1. 中南大学, 湖南 长沙 410083) \\ (2. 烟台南山学院, 山东 烟台 265713)
}

\begin{abstract}
摘 要: 分别采用金相, 扫描电镜, X射线衍射, 电子探针和波谱分析的手段, 对一种加入不同铈含量 $(0,0.1,0.3$, and 0.5 , 质量分数, \% 的新型 $\mathrm{Al}-\mathrm{Cu}-\mathrm{Li}$ 合金的铸态微观结构进行了研究。结果表明：随着含铈量的增加，晶粒得到很大程度的细化; 在含铈量不超过 $0.3 \%$ 的所 有试验合金中，均观察到了一种 $\mathrm{Mg} \mathrm{Ag}$ 富集的 $\mathrm{Al}_{7} \mathrm{Cu}_{4} \mathrm{Li}$ 中间相; 当含铈量达到 $0.5 \%$, 一种新型的灰色 $\mathrm{CuSi}(\mathrm{AgMg})$ 相出现; 然而粗大的 杆状 $\mathrm{Al}_{2} \mathrm{CuLi}$ 相在含铈量达到 $0.3 \%$ 就已经完全消失。分析表明：铈添加导致本试验合金中的中间相的析出序列和凝固行为发生了改变; 同时分析发现在合金凝固过程中产生的一种先析 $\mathrm{Al}_{8} \mathrm{Cu}_{4} \mathrm{Ce}$ 相, 不但能够促进晶粒形核, 同时能够阻止晶粒进一步长大, 最终导致含铈的 铸态合金晶粒得到细化。
\end{abstract}

关键词： $\mathrm{Al}-\mathrm{Cu}-\mathrm{Li}$ 合金; 铈; 晶粒细化; 中间相

作者简介: 余金祥, 男, 1984 年生, 博士生, 中南大学材料科学与工程学院, 湖南 长沙 410083, E-mail: $834139001 @ q q . c 0 m$ 